\title{
Pathologic Complete Remission in a Patient with Locally Advanced Unre- sectable Intrahepatic Cholangiocarcinoma Treated with Chemotherapy
}

\author{
Hyo Jun Yang', Ji Kon Ryu', Woo Hyun Paik', Sang Hyub Lee', Yong-Tae Kim', Kyoungbun Lee ${ }^{2}$ \\ Departments of IInternal Medicine and Liver Research Institute, ${ }^{2}$ Pathology, Seoul National University College of Medicine, Seoul, Korea
}

\begin{abstract}
A 54-year-old female with postprandial dyspepsia and abdominal pain was diagnosed as locally advanced unresectable intrahepatic cholangiocarcinoma by radiologic imaging studies resulting in invasion to bilateral main bile duct and right portal vein. The patient underwent extended right hepatectomy and portal vein resection after gemcitabine and cisplatin combined chemotherapy for a total of 40 cycles after the diagnosis. Final pathology showed, followed by pathological complete remission, without any residual cancer cell. The patient has survived for over 6 years without any evidence of recurrence. This case suggests that locally advanced intrahepatic cholangiocarcinoma, which can't be resected, was also proved to be capable of pathological complete remission with active chemotherapy, and long-term survival could be achieved. Therefore, active multidisciplinary approach and patient-oriented treatments using various methods should be considered for locally advanced unresectable intrahepatic cholangiocarcinoma.
\end{abstract}

Korean J Pancreas Biliary Tract 2017;22(4):188-192

Keywords: Bile duct cancer, Cholangiocarcinoma, Chemotherapy $\begin{array}{lr}\text { Received } & \text { Sep. 4, 2017 } \\ \text { Revised } & \text { Oct. 9, 2017 } \\ \text { Accepted } & \text { Oct. 10, 2017 }\end{array}$

Corresponding author : Ji Kon Ryu

Department of Internal Medicine and Liver Research Institute, Seoul National University College of Medicine, 101 Daehak-ro, Jongro-gu, Seoul 03080, Korea

Tel. +82-2-2072-1962 Fax. +82-2-762-9662

E-mail; jkryu@snu.ac.kr

This is an Open Access article distributed under the terms of the Creative Commons Attribution Non-Commercial License (http:/ creativecommons.org/licenses/by-nc/3.0/) which permits unrestricted non-commercial use, distribution, and reproduction in any medium, provided the original work is properly cited.

Copyright $@ 2017$ by The Korean Journal of Pancreas and Biliary Tract

\section{서 론}

담관암은 담도 상피세포에서 발생하는 암종으로, 원발성 간 암의 $10-20 \%$ 를 차지하며 그 해부학적 위치에 따라 간내, 간 외, 간문부 담관암으로 나눌 수 있다. 그중에서도 간내담관암 은 전체 담관암의 6-8\%로 가장 드물지만, 세계적으로 그 유병 률이 점점 증가하고 있는 추세이며 사망률 또한 증가하고 있 다. ${ }^{1,2}$ 뚜렷한 증상이 없어 $65 \%$ 이상의 대부분의 환자들이 진
단 당시 절제 불가능한 상태로 발견되며, 치료를 하지 않는 경 우 중앙생존기간이 3-6개월에 불과할 정도로 그 예후가 매우 나쁜 암 중 하나이다. ${ }^{3}$ 치료는 환자의 증상, 활동도, 암종의 크 기 및 분화도에 따라 항암화학 치료, 방사선 치료, 표적 치료 제, 경동맥화학요법, 고주파절제술 등 다양한 방법이 있으나 근치적 치료는 수술적 절제가 유일하며, 절제 불가능한 간내 담관암의 표준 치료는 아직까지 잘 알려져 있지 않다. ${ }^{4}$ 특히 항 암화학 치료 시행 후 병리학적 완전 관해로 판정된 증례는 국 
내에는 보고가 없다.

이에 저자들은 1 개월 전부터 발생한 식후 소화불량 및 복통 을 주소로 내원하여 국소 진행성 간내담관암으로 진단받았으 나, 약 3년간 총 40 주기의 전신 항암화학 치료 이후 수술적 절 제를 거쳐 병리학적 완전 관해 판정을 받아 5년 이상 장기생존 중인 환자 1 예를 경험하였기에 보고하는 바이다.

\section{증 례}

54 세 여자가 내원 1 개월 전부터 시작된 식후 소화불량 및 복 통을 주소로 타 병원 방문하여 시행한 복부 초음파 검사에서 간내 종괴가 발견되어 추가 평가를 위해 본원 소화기내과 외 래로 방문하였다. 통증은 지속적이면서 심해지는 양상이었고, 한 달간 $8 \mathrm{~kg}$ 의 체중 감소가 동반되어 있었다. 황달은 내원 당 시에는 동반되지 않았다. 환자는 3년 전부터 고혈압과 당뇨로 약물을 복용하며 조절 중이었고, 그 외 결핵이나 간담도 질환 의 과거력은 없었다. 가족력으로는 부모 모두 고혈압, 큰 언니 가 당뇨가 있는 것 외에는 악성 종양 등의 병력은 없었다. 음주 력, 흡연력은 모두 부인하였다.

입원 당시 활력 징후는 혈압 $145 / 95 \mathrm{mmHg}$, 맥박은 82 회/ 분, 호흡수는 20 회/분, 체온은 $36^{\circ} \mathrm{C}$ 였다. 신체검진에서 의식 은 명료하였고, 결막 빈혈이나 공막 황달은 없었다. 복부는 편 평하였고, 장음은 정상이었으며, 압통이나 반발통은 없었고, 종괴는 촉진되지 않았다. 말초혈액에서 백혈구 $9,940 / \mathrm{mm}^{3}$, 혈 색소 $13.0 \mathrm{~g} / \mathrm{dL}$, 혈소판 $309,000 / \mathrm{mm}^{3}$ 였다. 일반화학 검사에서

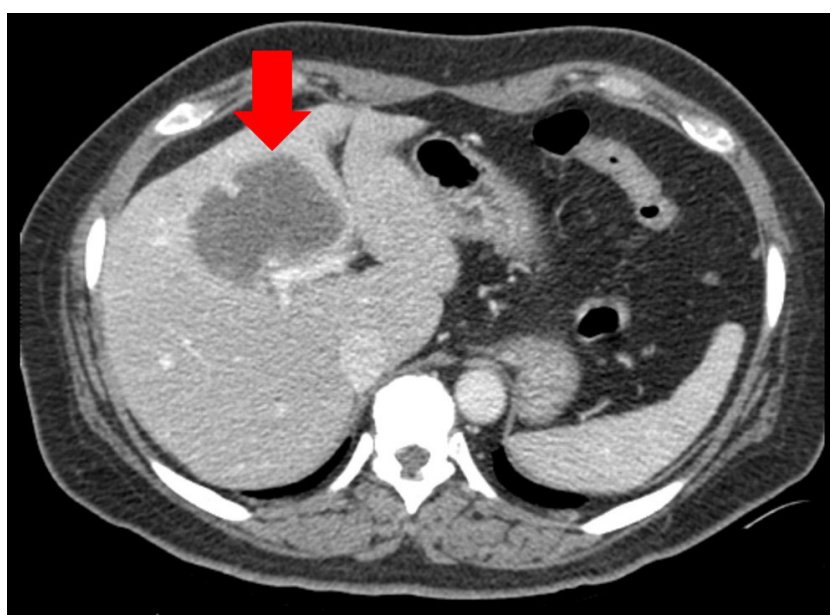

Fig. 1. Initial abdominal computed tomography findings. A $7.0 \mathrm{~cm}$-sized low attenuated mass is shown in the $\$ 8 / 4 / 5$ of the liver (arrow). There is an invasion of tumor upon bilateral main intrahepatic duct and right portal vein
혈청 총 단백 $8.0 \mathrm{~g} / \mathrm{dL}$, 알부민 $4.6 \mathrm{~g} / \mathrm{dL}$, aspartate aminotransferase (AST) $231 \mathrm{IU} / \mathrm{L}$, alanine aminotransferase (ALT) 220 IU/L, 총빌리루빈 $2.4 \mathrm{mg} / \mathrm{dL}$, blood urea nitrogen $10 \mathrm{mg} / \mathrm{dL}$, 크레아티닌 $0.96 \mathrm{mg} / \mathrm{dL}$, alkaline phosphatase (ALP) $509 \mathrm{IU} / \mathrm{L}$, gamma-glutamyltransferase ( $\gamma$-GT) 1,591 IU/L로 경미한 황달 이 있었고 간 및 담도 관련 수치인 AST, ALT, ALP, r-GT 모두 증가되어 있는 소견을 보였다. 또한, 암표지자 검사에서는 carbohydrate antigen (CA) 19-9, $113 \mathrm{U} / \mathrm{mL}$ (0-37), 알파태아 단백 $2.7 \mathrm{U} / \mathrm{mL}(0-20)$ 로 CA 19-9가 상승되어 있는 것이 확인 되었다. 또한 복부전산화단층촬영에서 간의 4 번, 5 번, 8 번 엽 에 걸쳐 양측 중심 간내담도와 우측 간문맥을 침범하고 있는 약 $7 \mathrm{~cm}$ 크기의 조영증강이 되지 않는 종괴가 발견되었다(Fig. 1). 이후 이 종괴에 대해 경피적 간조직검사를 시행하였고, 그 결과 선암종으로 확인되었으며(Fig. 2), 양측 중심 간내담도 및 우측 간문맥으로의 침범 소견으로 인해 완전절제가 불가능 한 국소 진행성 간내담관암으로 진단되었다.

이후 점차 담관암에 의한 폐쇄성 황달이 발생함에 따라 경 피경간 담즙배액술을 시행하였고, 이와 함께 완화 목적의 항 암화학요법으로 3 주 주기의 gemcitabine 및 cisplatin 병합 요 법을 시작하였다. 이후 양측 간내담관에 2 개의 금속 스텐트를 삽입한 뒤 경피경간 담즙배액관을 제거하였으며, 약 3년간 총 40 주기의 병합 항암화학요법을 지속하는 동안 CA 19-9는 지 속적으로 감소하여 1년 후 $113 \mathrm{U} / \mathrm{mL}, 2$ 년 후 $22 \mathrm{U} / \mathrm{mL}(0-37)$ 로 감소하였다.

40 주기의 항암화학요법으로 종괴의 크기는 초기 $7 \mathrm{~cm}$ 에서 약 $3 \mathrm{~cm}$ 까지 줄어들었으며, 이는 표적 병변의 장경이 $30 \%$ 이

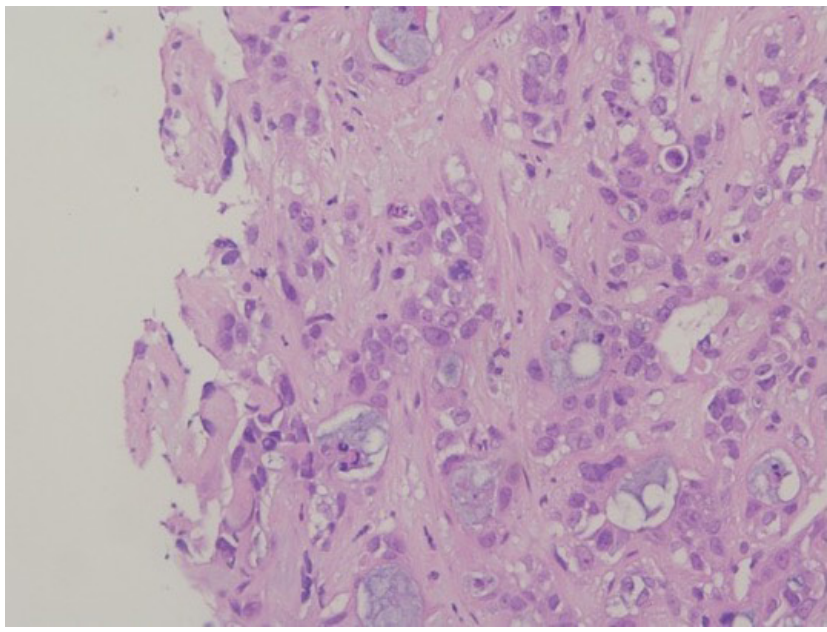

Fig. 2. Initial biopsy samples of the liver shows a histopathological classification of adenocarcinoma. (H\&E stain, $\times 400$ ) 

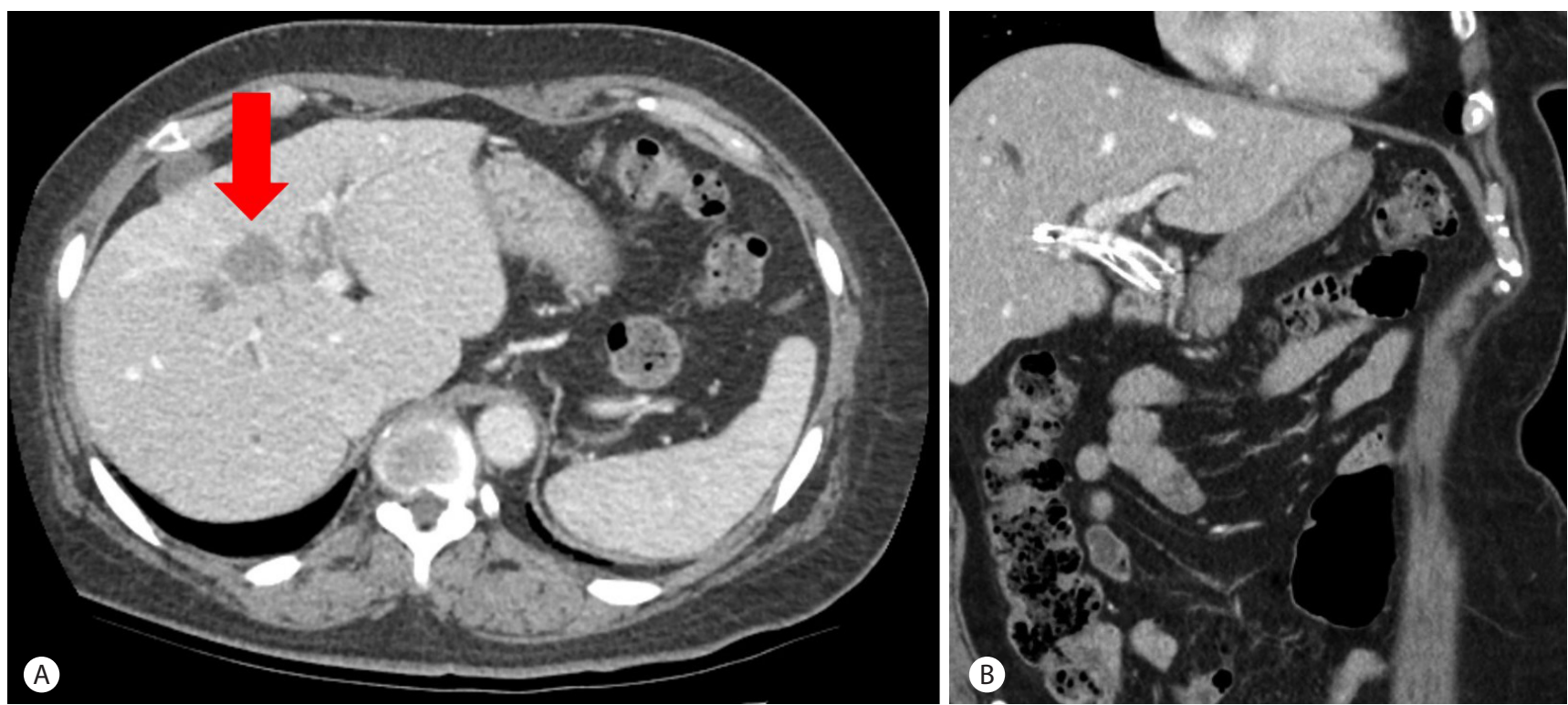

Fig. 3. Follow-up abdominal computed tomography findings after chemotherapy. (A) Image at after 40th chemotherapy. The size of low attenuated mass is about $3.0 \mathrm{~cm}$ (arrow). (B) Coronal view shows a disappearance of an invasion of tumor into right portal vein.

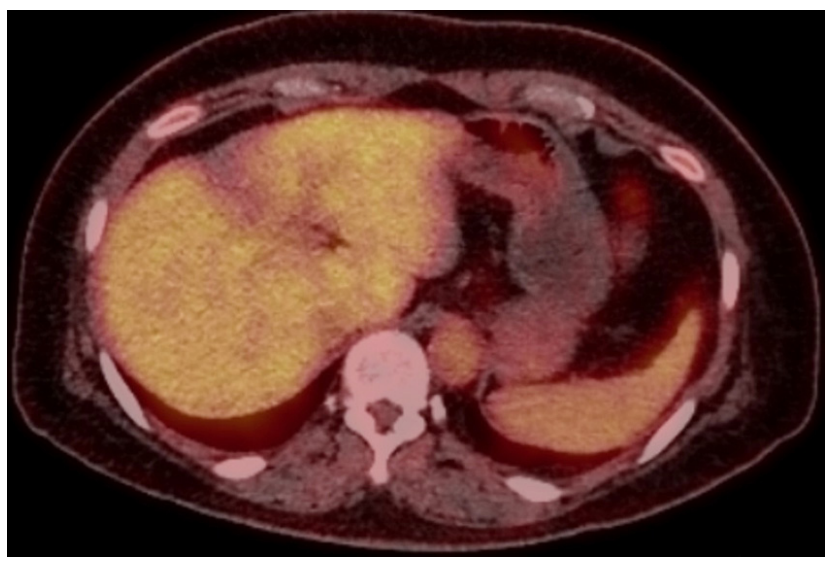

Fig. 4. Pre-operational positron emission tomography findings. There are no abnormal hypermetabolic lesions in the liver.

상 감소한 것이므로 RECIST 기준에 따라 영상의학적 부분 관 해로 판단하였다(Fig. $3 \mathrm{~A})$. 또한 종괴의 크기가 작아지면서 우 측 간문맥으로의 침범 소견이 소실된 것이 확인되었으며(Fig. $3 \mathrm{~B})$, 양전자단층촬영 검사에서 대사가 항진된 부위가 관찰되 지 않았다(Fig. 4). 따라서 이를 종합하였을 때 근치적 절제가 가능할 것으로 판단하여 확대 간우엽절제술 및 간문맥 구역절 제술을 시행하였다(Fig. $5 \mathrm{~A}$ ). 수술 검체에 대한 최종 병리 보고 에서 항암화학요법 이후의 상태이며, 총 3 개의 림프절에서 전 이는 발견되지 않았으며, $2.5 \times 2.3 \times 2.2 \mathrm{~cm}$ 의 섬유화된 결절 외에는 병리학적으로 잔존암이 관찰되지 않아 병리학적 완전
관해가 확인되었다(Fig. 5B, C). 이후 추가 치료 없이 현재까지 3 년 이상 주기적으로 외래에서 경과관찰 중이며, 수술 3 년 후 복부전산화단층촬영에서 재발의 증거는 없으며 특별한 증상 이 없는 상태이다(Fig. 6).

\section{고 찰}

본 증례는 식후 소화불량 및 복통을 주소로 내원한 54세 여 자 환자가 절제 불가능한 국소 진행성 간내담관암으로 진단 된 후 완화 목적의 총 40 주기의 gemcitabine 및 cisplatin 병합 항암화학요법 후 확대 간우엽절제술 및 간문맥 구역절제술을 시행 받은 뒤 병리학적 완전 관해로 판정되어 별다른 치료 없 이 3 년 이상 경과관찰 중인 환자의 증례이다. 환자는 진단 시 점으로부터 6 년 이상의 장기 생존을 보이는, 매우 드문 예라고 할 수 있다.

담관암 중에서도 간내담관암은 유병률이 낮다고 알려져 있 으나 2001년 발표된 연구 결과에 따르면 미국과 영국에서 간 내담관암의 유병률이 점차 증가하고 있으며, 미국에서는 지난 10-20년간 간내담관암이 원발성 간암에 연관된 사망의 주요 원인임이 밝혀져 그 임상적 중요성이 점차 부각되고 있다. ${ }^{5,6}$ 절제 불가능한 간내담관암의 중앙생존기간은 3-6개월에 불과 하며, ABC-02 임상시험을 통해 증명된 gemcitabine과 cisplatin 2 제 병합요법을 시행한 경우 11.7 개월로 약간의 생존기간 

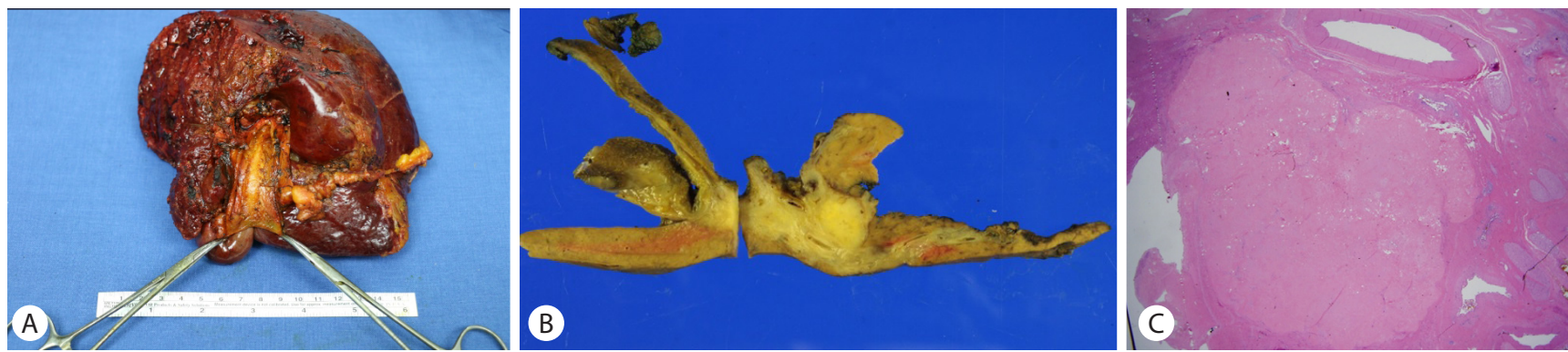

Fig. 5. (A) Gross specimen of extended right hemi-hepatectomy with portal vein segmental resection. (B) Gross findings of resected specimen. The 2.5 $\times 2.3 \times 2.2 \mathrm{~cm}$ sized solid fibrotic round nodule is shown in the right intrahepatic duct. (C) Microscopic findings of resected specimen shows hyalinized collagenous mass in the right intrahepatic duct (H\&E stain, $\times 10)$.

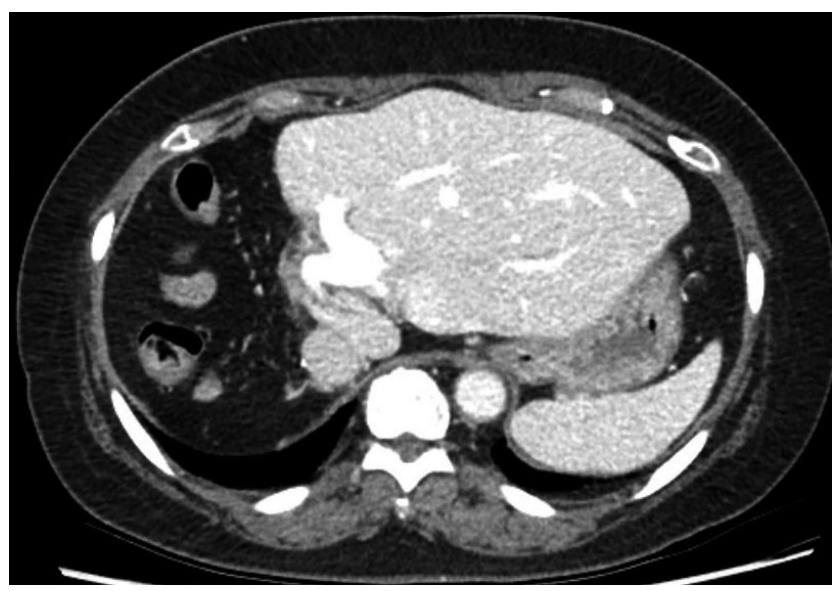

Fig. 6. Follow-up abdominal computed tomography (CT) findings 3 years after surgery. These CT Images show that there is no evidence of tumor recurrence.

증가는 있으나 여전히 예후는 불량한 실정이다. ${ }^{2,7}$

외국 문헌을 찾아보았을 때, 담관암에 대해 gemcitabine과 cisplatin 2제 병합요법을 시행한 연구에서 병리학적 완전 관해 가 온 경우는 86예 중 1예뿐이었으며, 7 gemcitabine과 oxaliplatin 2제 병합요법으로는 133 예 중 3 예에 불과하였다. ${ }^{8}$ 또한, 이 연구들은 간외담관암을 포함한 모든 담관암에 대해 시행되었 기 때문에, 유병률을 고려하여 보았을 때 이 중 간내담관암 증 례는 극히 드물 것으로 사료되며, 장기간 재발 여부는 확인되 지 않는다. 따라서 이번 증례의 환자는 수술적 절제가 불가능 한 상태의 간내담관암이 항암화학요법만으로 병리학적 완전 관해에 이르러 장기간 재발 없이 지내고 있으므로 상당히 드 문 증례라고 볼 수 있다. 이는 이 환자에서 원격 전이는 없었던 점, 상대적인 영양 상태가 나쁘지 않았던 점, 담도내 스텐트를 통해 폐쇄성 황달을 방지하여 잔여 간기능을 최대한 보존한 점, 그리고 아직까지는 잘 밝혀지지 않으나 항암화학요법에
민감하게 반응하는 유전적인 원인 등이 복합적으로 작용하였 기 때문으로 생각된다.

이러한 절제 불가능한 국소 진행성 간내담관암의 경우 정해 진 권고안이 없어 외과, 내과, 영상의학과를 포함한 다학제적 접근을 통해 수술 여부 결정 등의 환자 맞춤형 치료를 하는 것 이 필요하며, 다양한 치료 방법에 대한 연구가 많이 진행되고 있다. 항암화학요법의 일환으로 gemcitabine 및 cisplatin 병 용요법 외에도 gemcitabine 및 oxaliplatin 등의 대안 병용요법 또한 전체 생존율에 큰 차이가 없다는 연구 결과가 알려져 있 다. ${ }^{9}$ 또한 표적 치료에 대한 연구도 활발하게 진행되고 있는데, epidermal growth factor receptor 표적 치료제인 erlotinib을 기존 gemcitabine 및 oxaliplatin 병용요법에 추가하여 진행한 3 상 연구에서는 전체 생존율에는 큰 차이가 없으나 약에 대한 반응 정도가 증가했다는 결과도 보고되고 있다. ${ }^{6.8}$ 이외에도 경 동맥화학요법, 고주파절제술 등에 대한 연구들도 활발히 진행 되고 있다. 최근에는 간내담관암에서 fibroblast growth factor receptor 2 fusion과 isocitrate dehydrogenase $1 / 2$ mutation을 표적으로 하는 연구가 진행 중이며, 흑색종이나 신장암의 치 료 패러다임을 바꾼 면역 치료의 일종으로 PD-L1 양성인 담관 암 환자에서 anti-PD-1 antibody인 pembrolizumab의 효과에 대한 임상시험 또한 진행 중에 있어 앞으로의 간내담관암 치 료에 있어서 항암화학요법이 보다 중요한 역할을 하여 환자들 의 예후를 개선시킬 수 있을 것으로 사료된다. ${ }^{10}$

국내에는 보고가 없는 매운 드문 본 증례를 통해 초기 진단 당시 절제가 불가능한 국소 진행성 간내담관암 또한 적극적인 항암화학요법을 통해 병리학적 완전 관해에 이르러 장기생존 을 도모할 수 있음을 알 수 있었다. 이에 최근 연구되고 있는 다양한 치료법들이 함께 적용된다면 추후 이와 비슷한 환자들 의 생존율 향상에도 성과가 있을 것이라 생각된다. 


\section{요 약}

식후 소화불량 및 복통을 주소로 내원한 54세 여자 환자가 영상 검사 및 간조직검사를 통해 절제 불가능한 국소 진행성 간내담관암으로 진단을 받았다. 환자는 진단 이후 총 40 주기 의 gemcitabine 및 cisplatin 병합 항암화학요법 이후 수술적 절 제가 가능하다고 판단되어 확대 간우엽절제술 및 간문맥 구역 절제술을 시행 받은 뒤 병리학적 완전 관해로 판정되어 추가 적 치료 없이 경과를 관찰하며 6년 이상 장기생존 중이다.

본 증례를 통해 절제가 불가능한 국소 진행성 간내담관암 또한 적극적인 항암화학요법을 통해 병리학적 완전 관해에 이 르러 장기생존을 도모할 수 있음을 알게 되었으며, 향후 이와 비슷한 환자의 치료에 있어 최근 연구되고 있는 다양한 방법 들을 이용한 적극적인 치료가 필요하다고 생각된다.

국문 색인: 간내담관암, 담도, 항암화학요법

\section{Conflicts of Interest}

The author has no conflicts to disclose.

\section{REFERENCES}

1. Shaib Y, El-Serag HB. The Epidemiology of Cholangiocarcinoma. Semin Liver Dis 2004;24:115-125.

2. Patel T. Increasing incidence and mortality of primary intrahepatic cholangiocarcinoma in the United States. Hepatology 2001;33:1353-1357.

3. Cunningham SC, Choti MA, Bellavance EC, Pawlik TM. Palliation of hepatic tumors. Surg Oncol 2007;16:277-291.

4. Brandi G, Venturi M, Pantaleo MA, Ercolani G, GICO. Cholangiocarcinoma: current opinion on clinical practice diagnostic and therapeutic algorithms: a review of the literature and a long-standing experience of a referral center. Dig Liver Dis 2016;48:231-241.

5. Khan SA, Taylor-Robinson SD, Toledano MB, Beck A, Elliott P, Thomas $\mathrm{HC}$. Changing international trends in mortality rates for liver, biliary and pancreatic tumours. J Hepatol 2002;37:806-813.

6. Esnaola NF, Meyer JE, Karachristos A, Maranki JL, Camp ER, Denlinger CS. Evaluation and management of intrahepatic and extrahepatic cholangiocarcinoma. Cancer 2016;122:1349-1369.

7. Valle J, Wasan H, Palmer DH, et al. Cisplatin plus gemcitabine versus gemcitabine for biliary tract cancer. N Engl J Med 2010;362:1273-1281.

8. Lee J, Park SH, Chang HM, et al. Gemcitabine and oxaliplatin with or without erlotinib in advanced biliary-tract cancer: a multicentre, openlabel, randomised, phase 3 study. Lancet Oncol 2012;13:181-188.

9. Weatherly J, Eckmann K, Patel D, et al. Chemotherapy outcomes for the treatment of unresectable intrahepatic and hilar cholangiocarcinoma: a retrospective analysis. J Clin Oncol 2011;29(4_suppl):271.

10. Jordan E, Abou-Alfa GK, Lowery MA. Systemic therapy for biliary cancers. Chin Clin Oncol 2016;5:65. 